\title{
WestVirginiaUniversity
}

THE RESEARCH REPOSITORY @ WVU

Volume 40 | Issue 3

Article 21

April 1934

\section{The American Doctrine of Judicial Supremacy}

Charles G. Baker

Follow this and additional works at: https://researchrepository.wvu.edu/wvlr

Part of the Jurisprudence Commons

\section{Recommended Citation}

Charles G. Baker, The American Doctrine of Judicial Supremacy, 40 W. Va. L. Rev. (1934).

Available at: https://researchrepository.wvu.edu/wvlr/vol40/iss3/21

This Book Review is brought to you for free and open access by the WVU College of Law at The Research Repository @ WVU. It has been accepted for inclusion in West Virginia Law Review by an authorized editor of The Research Repository @ WVU. For more information, please contact ian.harmon@mail.wvu.edu. 


\section{BOOK REVIEWS}

The American Doctrine of Judictal Supremiay. By Charles Grove Haines, $\mathrm{Ph} . \mathrm{D}$. Berkeley, California: University of California Press, 1932. Pp. 540.

This is a revised and enlarged edition of a work on this subject, published by the author in 1914. It is a most comprehensive and exhaustive study of a subject which has been little treated and which is largely taken for granted in this country. It must be admitted that it has not received much thought and little cognizance has been taken of the fact that our American theory of the doctrine is not at all universal and that it is the result of a development through many years prior to the formation of our government, and that the theory itself has been greatly enlarged and further developed in our own country.

Early in the work, the author points out that which must be realized before a real study of the subject is undertaken, to-wit, "The practice of the review of legislative acts by the courts is affected to no small degree by the control which legislatures exercise over the courts and over the constitution." The different methods of such control are then classified, the author showing the English, French and other systems found, concluding with a fuli discussion of the American system.

One of the most interesting features of this book is the historical background, both legal and political, of the ideas leading to the review of legislative acts by courts, and this is followed with an historical discussion of the development of the practice in the Colonial and Revolutionary periods of our country, including state precedents prior to 1789 , the issue of judicial review in the federal and state conventions and in the judiciary act of 1789 ; state precedents after 1789 and early federal precedents.

The author also develops the legal theories and principles involved in the establishment of the American Doctrine and asks the question, "Why were not all provisions of constitutions political laws as they are generally considered to be in Europe, and hence primarily to be interpreted and applied by legislatures as the dominant European practice requires?" He makes the statement, "The fact of the matter is that judicial review of legisIation was adopted as a practical device to meet a particular situation by shrewd men of affairs who knew what they wanted and who seldom expressed clearly the reasons which prompted their 
conclusions." From this point he develops the theory through the doctrines of natural law and rights, the distrust of legislative power, the theory of separation of powers, etc.

His chapter on the opposition to the theory is enlightening. He discusses the positions taken by such men as James Madison, Thomas Jefferson and others, and details the opposition to the theory by certain state courts, by the federal courts during certain periods of our history, particularly during the Jacksonian Democratic Era. There is a discussion of politics as it affected federal constitutional law, the author noting that Professor Felix Frankfurter once noted that "American constitutional law is more politics than law."

The theory is further reviewed through the Civil War period, the Dred Scott decision, etc., the Reconstruction period, and there is a discussion of the results on the theory of the changes in the personnel of the Supreme Court. The author notes certain changes in the scope and significance of the theory that have developed through the years and outlines recent criticisms by dissenting judges, labor leaders, liberals and radicals. Certain proposals to remedy the defects in the theory are noted and the author concludes with a chapter on the theories and fictions involved in the application of the doctrine.

Appendices note the acts of Congress invalidated by the Supreme Court; classifies the acts declared void; cites the provisions of written constitutions relating to the doctrine in foreign countries; lists the countries in which the legislative or executive departments are the guardians of the constitution and includes a most exhaustive biography.

It will thus be seen that the statement made in the first of this review, that the work is really comprehensive, is truly accurate. It is a book well worth the study of persons primarily interested in constitutional law. Indeed, the wonder is that a subject as important as the one with which this book"deals has gone so long without more exhaustive study.

Morgantown, West Virginia.

-Charles G. Baker. 